\author{
FORMS, CONTENTS AND MANAGEMENT \\ OF PREPARATION FOR (ACTIVE) AGEING \\ AND (ACTIVE) OLD AGE \\ [FORMY, OBSAH A RIADENIE PRIPRAVY \\ NA (AKTIVNE) STARNUTIE A (AKTIVNU) STAROBU]
}

\title{
Ctibor Hatar
}

doi: 10.18355/PG.2021.10.2.7

\begin{abstract}
The submitted study has a theoretical character, and it approaches the preparation for (active) aging and (active) old age from three perspectives its forms, the process of its management, and the orientation of its contents. Several sources confirm that this preparation can have manifold forms, it can take place in many types of the environment in various subjects, and it can be related to all age groups. The submitted study exclusively focuses on the educational preparation for (active) aging and (active) old age. The author presents its contents according to the age of learners.
\end{abstract}

Key words

(Active) aging, (active) old age, forms, contents, management, preparation

\section{Abstrakt}

Predkladaná štúdia, teoretického charakteru, približuje prípravu na (aktívne) starnutie a (aktívnu) starobu z troch perspektív - jej podoby, proces riadenia a obsahové zameranie. Viaceré zdroje potvrdzujú, že môže mat' rozmanité podoby, môže prebiehat' $\mathrm{v}$ rôznych typoch prostredia, skrze rôzne subjekty a môže sa týkat' všetkých vekových skupín. V centre pozornosti predkladanej štúdie je výlučne edukačná príprava na (aktívne) starnutie a (aktívnu) starobu. Jej obsah autor načrtáva podl'a veku edukantov.

\section{Kl'účové slová:}

(Aktívne) starnutie; (aktívna) staroba; formy, obsah, riadenie, príprava

\section{Úvod}

„Kto spokojne starne a vie utvárat' svoj život $v$ sociálnej jednote, preživa subjektívne lepšiu kvalitu života a zdravie a je menej náchylný na chorobu a potrebu opatery. Vzdelávanie vytvára pre to podmienky. “ 
Skôr než sa dostaneme $\mathrm{k}$ jadru problematiky prípravy na (aktívne) starnutie a (aktívnu) starobu, považujeme za dôležité uviest' tri okruhy problémov, ktoré, podl'a A. Kruseho (1994: 351), riešia vedy o výchove vo vzt'ahu k starobe:

1. vzdelávanie a príprava na starobu (vzdelávanie $k$ starobe) prostredníctvom nej získava človek ,pred vstupom do staroby“ fundamenty samostatného a zmysluplného starnutia;

2. vzdelávanie v biografickom kontexte (vzdelávanie v starobe) - musí sa rešpektovat' „vzdelávacia história“ človeka, t. j. obsahy vzdelávania a stratégie učenia, ktoré vychádzajú $\mathrm{z}$ historických, spoločenských a kultúrnych udalostí a procesov, v/na ktorých boli seniori zainteresovaní;

3. vzdelávanie v situačnom kontexte - autor, odvolávajúc sa na E. Webera (1988), podáva deskripciu troch vzdelávacích potrieb a úloh, a to a) všeobecné vzdelávacie potreby a úlohy, ktoré vychádzajú zo sociokultúrnej zmeny; b) typické vzdelávacie potreby a úlohy, ktoré súvisia $\mathrm{s}$ vývinovými úlohami; c) individuálne vzdelávacie potreby a úlohy, ktoré vychádzajú z kritických životných udalostí (in: Kruse, 1994: 351). ${ }^{1}$

Samotná príprava na starnutie a starobu sa môže uskutočňovat' 176 rozmanitým spôsobom, $v$ rôznych typoch prostredia, skrze rôzne subjekty a vo vzt’ahu k rôznym vekovým skupinám.

\section{Formy, obsah a manažment prípravy na (aktívne) starnutie a (aktívnu) starobu}

B. Balogova (2005) na základe teoretického a empirického skúmania nastolenej problematiky navrhla celospoločenskú (súvisí s reformou dôchodkového poistenia, politikou zamestnanosti starších l'udí, politikou sociálneho poistenia, podporou celoživotného vzdelávania...), podnikovú (ide napr. o identifikáciu zamestnancov, ktorí dosahujú dôchodkový vek, poznávanie ich zámerov, či pracovat' alebo nepracovat' d'alej, zosúladenie plánov zamestnanca $\mathrm{s}$ plánmi zamestnávatel'a, príprava a realizácia adaptačných opatrení, ako napr. outplacement ${ }^{2}$ ), sociálnu (ide o riešenie sociálnych problémov, napr. využívanie vol'ného času ${ }^{3}$ ) a svojpomocnú (ide

\footnotetext{
1 V našej publikácii plne rešpektujeme koncepty, rozpracované E. Liveckom (1979) a R. Cornanicovou (1998).

2 Outplacement - poradenstvo má v Nemecku dlhú tradíciu, pričom podl’a W. Hofmann (2001) sa chápe ako „poradenstvo a sprevádzanie od výpovede cez fázu novej profesijnej orientácie až k novej činnosti“ (in: Beelmann, 2011: 136). Ako podkategórie sa používajú pojmy Newplacement, Replacement či Inplacement (Beelmann, 2011: 136).

3 Podrobnejšie sa vol’nočasovým aktivitám v starobe venujú publikácie V. Holczerovej a D. Dvorackovej (2013), K. Janisa a J. Skopalovej (2016) a d'alších.

Slavonic Pedagogical Studies Journal, eISSN 1339-9055, ISSN 1339-8660, Volume 10 Issue 2, 2021
} 
o poskytnutie sociálnej opory cez Jednotu dôchodcov Slovenska alebo denné centrá, ktoré majú štatút svojpomocných hnutí) prípravu na vstup do dôchodku (Balogova, 2005: 104 - 117).

$\mathrm{Na}$ podobnom princípe funguje aj vekový manažment, ktorého opatrenia sa realizujú na troch úrovniach, a to:

1) individuálna úroveň (jednotlivec) - ciel'om je udržanie a obnova vlastnej zamestnatel'nosti za pomoci plánovania budúcnosti, celoživotného vzdelávania a postoja k vlastnému zdraviu;

2) organizačná úroveň (firma) - ciel’om je udržanie a rozvoj pracovných síl za pomoci sociálne zodpovedného správania zamestnávatel'ov či jednotlivých pilierov vekového manažmentu ${ }^{4}$;

3) národná, príp. regionálna úroveň (spoločnost') - ciel’om je sociálna súdržnost' a podpora hospodárskeho rastu za pomoci sociálnej politiky, vrátane dôchodkovej politiky a politiky zamestnanosti, a vzdelávacieho systému (Cimbalnikova et al., 2012: 34).

M. Serak (2019: 31) uvádza, že príprava na starnutie a starobu môže mat' podobu aktívnu (človek si sám upravuje prostredie a životný rámec) a pasívnu (človek sa prispôsobuje svojmu prostrediu).

Z hl'adiska časového môžeme podl'a B. Balogovej (2005) a d'alších autorov (napr. V. Pacovskeho, 1990; R. Cornanicovej, 1998 a i.) rozlišovat':

1. dlhodobú prípravu na starobu - mala by sa realizovat' $v$ priebehu celého života $\mathrm{s}$ akcentom na výchovu $\mathrm{k}$ zmysluplnému životu, spoločenskej aktivite, rozvoju osobných záujmov a tvorivej činnosti;

2. strednodobú prípravu na starobu - mala by sa začat' okolo 45. roku života, dôraz by mal byt' kladený na zdravý životný štýl, pestovanie mimopracovných aktivít, upevňovanie sociálnych kontaktov mimo vlastného pracoviska, čím sa dospelému cielavedome pripravuje nový $\operatorname{program}^{5}$;

3. krátkodobú prípravu na starobu - mala by začat' asi 3 až 5 rokov pred vstupom do dôchodku, pričom dospelých treba dostatočne informovat' o d'alších možnostiach aktívneho spôsobu života v dôchodku (Balogova, 2005: 112 - 113).

Príprava na (aktívne) starnutie, (aktívnu) starobu a na odchod do starobného dôchodku sa d'alej môže členit' podl'a miesta, v ktorom by mohla

4 Odborníci z Fínskeho inštitútu pracovného zdravia definovali osem pilierov vekového manažmentu na úrovni podniku, a to znalost' problematiky veku, ústretový postoj voči veku, manažment, ktorý dobre rozumie individualite a rozdielnosti, kvalitná a funkčná veková stratégia, dobrá pracovná schopnost', vysoká úroveň kompetencií, dobrá organizácia práce a pracovného prostredia a spokojný život (Cimbalnikova et al., 2012: 39).

5 B. Balogova (2005: 112) sa zmieňuje o „náhradnom “ programe. H. Haskovcova (2010: 125) podrobuje istej kritike toto označenie a odporúča používat' pojem ,,druhý životný program “, ktorý možno koncipovat' predovšetkým na základe poznania potrieb starnúceho a starého človeka, ktoré sa nevzt’ahujú len na jeho zdravie a materiálno-finančné zabezpečenie, ale tiež na potrebu mat' svoj domov, kde mu je prejavená úcta a láska. 
prebiehat', na prípravu v domácom/rodinnom prostredí (v súkromí), v prostredí školy (v čase prípravy na povolanie), v prostredí firmy/organizácie (pri výkone zamestnania), v prostredí záujmových a dobrovol'níckych skupín (vo vol'nom čase) alebo v prostredí celej spoločnosti (všeobecné sociálnopolitické nariadenia).

Podl'a veku osôb, ktoré sa majú na starnutie, starobu, príp. odchod do starobného dôchodku pripravovat', môžeme rozlišovat' prípravu detí, mládeže, dospelých v pracovne činnom veku a seniorov. Povedané slovami R. Cornanicovej (1998: 124), pôjde o preseniorskú, proseniorskú a seniorskú edukáciu.

Nasledovná tabul'ka ilustruje postup riadenia prípravy na aktívne starnutie a aktívnu starobu. ${ }^{6}$

\section{Tabul'ka č. 1: Manažment prípravy na aktívne starnutie a aktívnu starobu}

\begin{tabular}{|c|c|c|c|c|}
\hline $\begin{array}{r}V_{I} \\
v \text { podol } \\
\text { na aktivne st } \\
\text { (ce }\end{array}$ & $\begin{array}{l}\text { ívajúci faktor } \\
\text { cielenej prípravy } \\
\text { rnutie a aktívnu starobu } \\
\text { rôzne profesie) }\end{array}$ & $\begin{array}{c}\text { Ovplyvňovaný } \\
\text { subjekt }\end{array}$ & \multicolumn{2}{|c|}{$\begin{array}{l}\text { Ovplyvnený subjekt/ } \\
\text { výsledok prípravy }\end{array}$} \\
\hline $\begin{array}{l}\text { Ekonomická } \\
\text { príprava }\end{array}$ & $\begin{array}{l}\text { ekonóm, finančný } \\
\text { poradca }\end{array}$ & \multirow{5}{*}{$\begin{array}{l}\text { ČLOVEK, } \\
\text { ovplyvnený } \\
\text { faktormi } \\
\text { z vnútorného } \\
\text { a vonkajšieho } \\
\text { prostredia, }\end{array}$} & \multirow{5}{*}{ 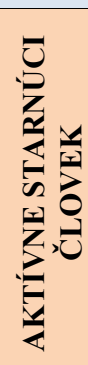 } & \multirow{5}{*}{ 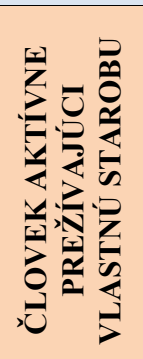 } \\
\hline $\begin{array}{l}\text { Sociálna } \\
\text { príprava }\end{array}$ & $\begin{array}{l}\text { sociológ, sociálny } \\
\text { pracovník }\end{array}$ & & & \\
\hline $\begin{array}{l}\text { Psychologic } \\
\text { ká príprava }\end{array}$ & psychológ & & & \\
\hline $\begin{array}{l}\text { Spirituálna } \\
\text { príprava }\end{array}$ & kňaz, rehol'ník & & & \\
\hline $\begin{array}{l}\text { Telesná } \\
\text { príprava }\end{array}$ & $\begin{array}{l}\text { tréner, telovýchovný } \\
\text { lekár }\end{array}$ & & & \\
\hline
\end{tabular}

6 Pri tvorbe tohto návrhu postupu (fáz) riadenia sme vychádzali z názvoslovia a systému školského manažmentu, resp. manažmentu edukácie dospelých (vid' napr. Horak, 2002; Porubska - Durdiak, 2005; Pisonova et al., 2017) a z behaviorálnej teórie (porovnaj napr. Striezenec, 1999; Hartl - Hartlova, 2010).

7 Treba však uviest', že G. Unkelbach-Romussi (1997: 106 - 115) už v 90-tych rokoch detailne popisovala tematické okruhy (psychologické, psychosociálne, životstvárňujúce a svetonázorové aspekty; zdravotné aspekty; hospodárske aspekty; právne aspekty; zariadenia, služby, ponuky pre staršie obyvatelstvo), vymedzené švajčiarskou organizáciou Pro Senectute (viac o organizácii: https://www.prosenectute.ch/) a inými autormi, ktoré možno chápat' ako obsah podujatí, zameraných na prípravu na starobu (a snád' aj na starnutie). Autorka tiež bližšie popisuje/analyzuje antropologické, sociologické, psychologické a vol'nočasovo-pedagogické predpoklady didaktiky/metodiky prípravy na starobu (Unkelbach-Romussi, 1997: 51 - 78).

Slavonic Pedagogical Studies Journal, eISSN 1339-9055, ISSN 1339-8660, Volume 10 Issue 2, 2021 


\begin{tabular}{|l|l|l|l|l|}
\hline $\begin{array}{l}\text { Edukačná } \\
\text { príprava }\end{array}$ & $\begin{array}{l}\text { PEDAGÓG, } \\
\text { ANDRAGÓG }\end{array}$ & ktorom žije & & \\
\cline { 1 - 2 } $\begin{array}{l}\text { Iná } \\
\text { specificky } \\
\text { zameraná } \\
\text { príprava }\end{array}$ & d'alšie profesie & & \\
\hline
\end{tabular}

Zdroj: vlastné spracovanie

Tabul'ka č. 1 d’alej dokumentuje, že prípravou človeka na (aktívne) starnutie a (aktívnu) starobu sa môžu zaoberat' rôzne profesie, od ekonómov, cez sociológov, sociálnych pracovníkov, psychológov, duchovných, lekárov, až po edukačných pracovníkov, andragógov z tejto kategórie nevynímajúc.

Naše závery potvrdzuje aj M. Serak (2019: 27 - 28), ktorý konštatuje, že problematika prípravy na starnutie a starobu už nie je riešená iba ako sociálna, politická a ekonomická záležitost', ale tiež ako „edukačná téma“.

Predmetom nášho záujmu sa preto stáva tzv. edukačná príprava na (aktívne) starnutie a (aktívnu) starobu. Tabul'ka č. 2 názorne ilustruje obsah ${ }^{9}$ prípravy na (aktívne) starnutie a (aktívnu) starobu $\mathrm{z}$ hl'adiska veku ${ }^{10}$ edukantov.

Edukačné aktivity, zamerané na (aktívne) starnutie a (aktívne) prežívanie seniorského veku, môžu byt' zostavené podl'a jednotlivých zložiek výchovy (pozri napr. Masarik et al., 1994; Perhacs - Paska, 1995; Cornanicova, 1998), oblastí záujmovej činnosti (porovnaj napr. Masarikova Masarik, 2002; Serak, 2009; Kryston et al., 2011), zložiek osobnosti (viac o tom napr. Hotar - Paska - Perhacs et al., 2000; Perhacs, 2011) alebo podl'a aspektov/stránok (bytia, vývinu) osobnosti (porovnaj napr. Vagnerova, 2000; Balogova, 2005; Strizenec, 2007; Perhacs, 2011; Kovac, 2013), t. j. edukačné

8 Podobné faktory ovplyvňujú aj kvalitu života človeka (porovnaj napr. Tokarova, 2002; Hermanova, 2012a,b).

$9 \quad$ K vybraným témam, prezentovaným $\mathrm{v}$ tabul'ke č. 2, odporúčame publikácie nasledovných autorov: Komensky, 1992; Wingchen, 1995; Perhacs - Paska, 1995; Unkelbach-Romussi, 1997; Cornanicova, 1998, 2011; Masarikova - Masarik, 2002; Stilec, 2004; Walsh, 2005; Strizenec, 2007; Serak, 2009, 2019; Krivohlavy, 2011; Rabusicova - Kamanova - Pevna, 2011; Rackova - Ochaba, 2012; Zimermanova, 2012a,b; Cimbalnikova et al., 2012; Petrova Kafkova, 2012; Lalik, 2012, 2013; Jerabek et al., 2013; Kupcova, 2014; Novotny et al., 2014; Lenhardtova - Frk - Tlucakova, 2015; Spatenkova - Smekalova, 2015; Tomczyk, 2015; Rabusicova et al., 2016; Gracova - Selecky, 2017; Vavrikova, 2017; Jedlickova, 2017, 2021; Vavrikova - Hudecova, 2018; Sladkayova, 2019; Koricina, 2020, 2021 a i., ktoré nás inšpirovali pri koncipovaní obsahu prípravy na (aktívne) starnutie a (aktívnu) starobu, resp. ktoré považujeme vo vzt’ahu k obsahu predmetnej prípravy za významné.

10 Pri pomenovaní vekovej skupiny možno vychádzat' z rôznych odborov, resp. ich odvetví, v našej práci sme použili členenie (názvoslovie) veku, ktoré sa uplatňuje v sociológii (napr. Alan, 1989; Sak - Kolesarova, 2012; Urban, 2017), vo vývinovej psychológii (napr. Vagnerova, 2000) a v demografii (napr. Jurcova, 2002). 
aktivity zamerané na biologickú, psychickú, sociálnu (resp. psychosociálnu) a duchovnú stránku osobnosti človeka v rámci systému formálneho, neformálneho a informálneho vzdelávania (pozri napr. Svec, 2008).

Tabul'ka č. 2: Obsah prípravy na (aktivne) starnutie
a (aktívnu) starobu z hl'adiska veku edukantov

\begin{tabular}{|c|c|}
\hline \multicolumn{2}{|c|}{ (AKTÍVNE) STARNUTIE a (AKTÍVNA) STAROBA } \\
\hline $\begin{array}{l}\text { DETI } \\
\text { a MLÁDĚ̌ }\end{array}$ & 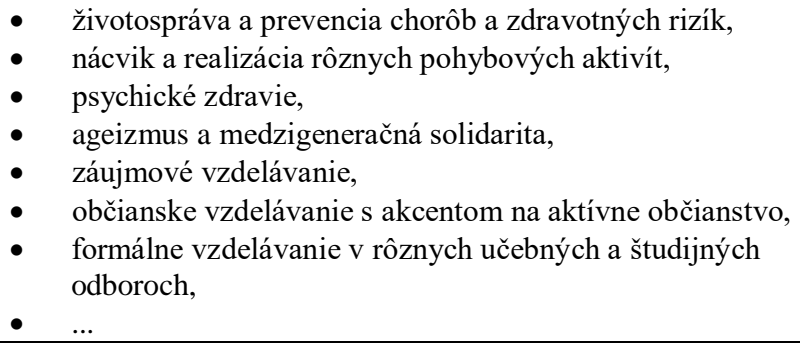 \\
\hline $\begin{array}{l}\text { DOSPELÍ } \\
\text { (v pracovne } \\
\text { činnom } \\
\text { veku) }\end{array}$ & 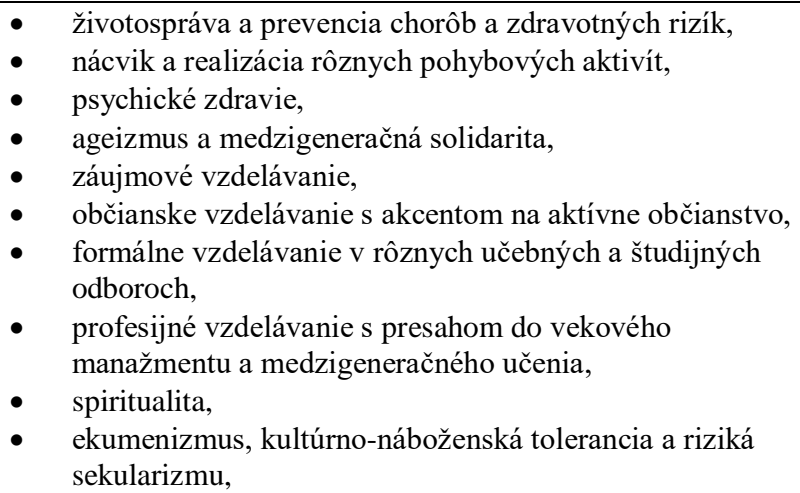 \\
\hline
\end{tabular}

11 Rozdiel v tom, či pôjde o bežné starnutie a bežne prežívanú starobu alebo o aktívne starnutie a aktívnu starobu spočíva najmä v človekom preferovanom prístupe (aktívny, činorodý, neraz bez potreby stimulácie verzus všedný, až pasívny). Čo možno považovat' za aktivitu a čo za neaktivitu v kontexte predkladanej problematiky precízne objasňuje M. Petrova Kafkova (2019: 200 - 201) alebo dokument Aktiv Altern: Rahmenbedingungen und Vorschlaege fuer politisches Handeln (2002: 12).

Rozdiel medzi úspešným starnutím/zdravou (aktívnou) starobou, obvyklým starnutím/starobou a patologickým starnutím vysvetl'ujú R. Cevela, Z. Kalvach a L. Celedova (2012: 28). Pojmom aktívne starnutie a aktívna staroba sa venujeme v publikácii Active Ageing and Active Old Age in the Educational Context (Hatar, C., 2019).

Slavonic Pedagogical Studies Journal, eISSN 1339-9055, ISSN 1339-8660, Volume 10 Issue 2, 2021 


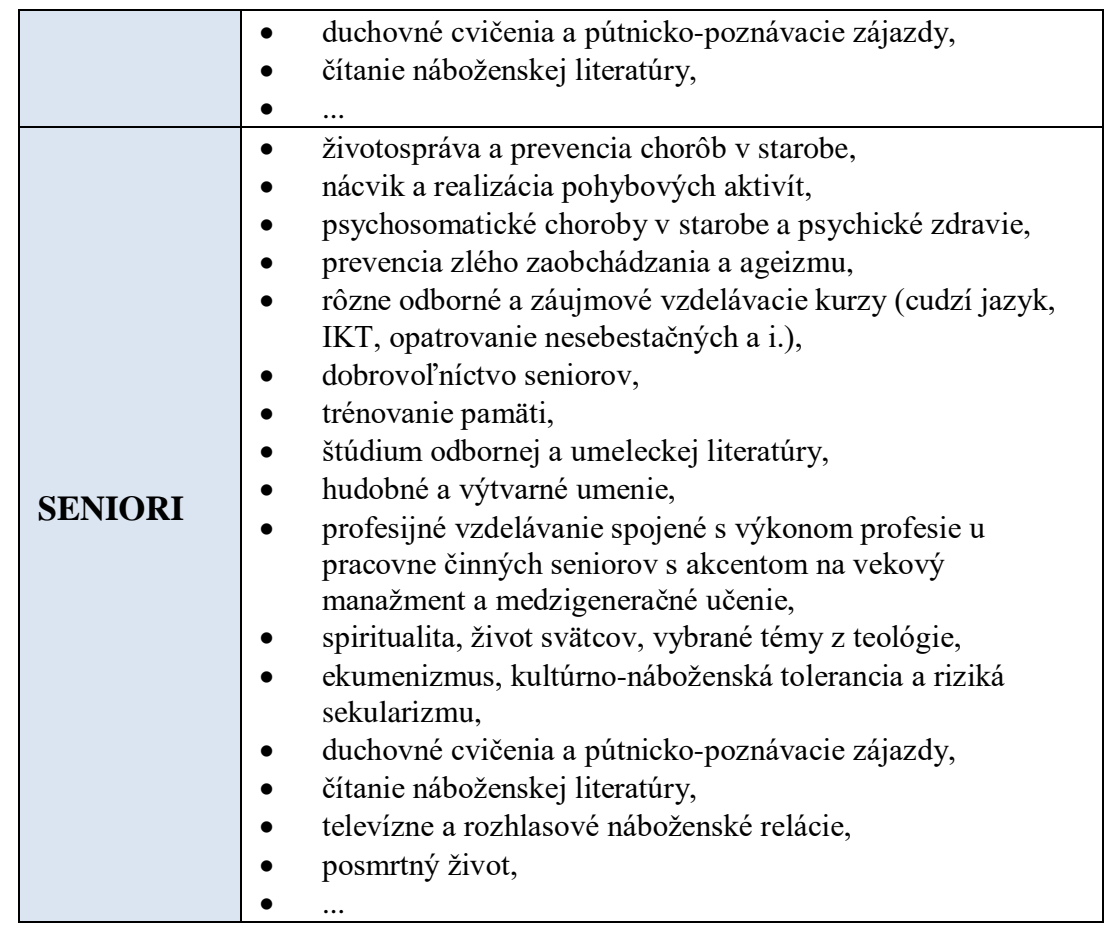

G. Theunissen (2002: 83) uvádza klúčové témy, predstavujúce náplň všeobecného vzdelávania osôb s učebnými t’ažkost'ami a viacnásobným postihnutím v neskorom dospelom veku a v starobe, ktoré sú svojím spôsobom použitel'né aj na intaktných dospelých a seniorov:

- príprava na starnutie, starobu a dôchodok;

- $\quad$ práca so životnými príbehmi;

- $\quad$ práva seniorov (v rezidenciálnych podmienkach);

- (psychické a fyzické) zdravie a stravovanie;

- bývanie a život v starobe, vrátane inštitucionalizácie;

- $\quad$ samostatnost', sebaurčujúce starnutie a asistenčné služby;

- produktivita a sebarozvoj v seniorskom veku;

- vzt'ahy v seniorskom veku;

- zvládanie strát a chorôb, vrátane sprevádzania zomierajúcich a práce so smútkom.

Aj M. Serak (2019: 33 - 35) sa pokúsil navrhnút' okruh tém pre prípravu na starobu. Ide o nasledovné oblasti: zdravie a životný štýl, 
spoločenské a organizačné aspekty, ekonomické a materiálne zabezpečenie, psychické a intelektuálne aspekty, umieranie a smrt'.

Vzdelávacia ponuka tzv. inštrumentálneho charakteru môže byt', podl'a G. Theunissena (2002: 86), orientovaná na:

- domáce práce, ako napr. varenie, pečenie a pod.;

- praktické aktivity súvisiace so životom, ako napr. nakupovanie, starostlivost' o svoje telo, domácnost', rastliny atd'.;

- orientácia v priestore, napr. využívanie prostriedkov hromadnej dopravy a pod.;

- $\quad$ komunikácia a kultúrne techniky, medzi ktoré patrí napr. čítanie, písanie a počítanie;

- $\quad$ používanie a využívanie nových médií, resp. technológií;

- sociálne učenie, zamerané napr. na techniky riešenia konfliktov alebo výcvik v mediácii, a tréning tzv. všeobecných stratégií na riešenie problémov;

- telesný tréning, džoging mozgu, výcvik sebavedomia;

Obsahom prípravy na starnutie/starobu, resp. preseniorskej edukácie sa zaoberali aj C. Hatar a P. Jedlickova (2018), M. Ivancikova (2020), P. Jedlickova (2021), M. Koricina (2020, 2021) a jej psychologickou platformou aj M. Mueller de Morais (2019).

Základnou analýzou navrhovaných tém, resp. vzdelávacích ponúk sme dospeli k poznaniu, že témy možno rozdelit' do štyroch skupín, a to obsah prípravy súvisiaci sbiologickou, psychickou, sociálnou a spirituálnou/duchovnou stránkou osobnosti starnúceho človeka, resp. seniora.

\section{Namiesto záveru}

Ak teda prijímame koncept edukácie od S. Sveca (2015: 225 - 227), potom treba uviest', že má rovnaké opodstatnenie vo vzt’ahu k starším dospelým a seniorom ako vo vzt’ahu k mladším vekovým kategóriám, pričom jej podstata môže byt' napíňaná rôznorodým spôsobom a jej potenciál aj rôzne využívaný. ${ }^{12}$ O. Cepelka (2019: 39) konštatuje, že (v kontexte saturácie potrieb a kvality života) edukácia a) vytvára u dospelých fundament pre d'alšie vzdelávanie a jeho následné uplatnenie, resp. využitie v starobe, b)

12 F. Kolland (2010: 15 - 16) konštatuje, že celoživotné učenie sa spája so získavaním kompetencií a pre aktívne starnutie identifikuje pät' kompetencií, a to: 1) kognitívna kompetencia (prijímanie a chápanie súvislostí), 2) sociálna kompetencia (udržiavanie vyhovujúcich sociálnych vzt’ahov), 3) produktívna kompetencia (úsilie a výdrž), 4) sebakompetencia (schopnost' a pripravenost' na autonómne a zodpovedné konanie a na reflexiu vlastného a cudzieho konania), 5) orientačná kompetencia (orientácia v čase a v prostredí).

Slavonic Pedagogical Studies Journal, eISSN 1339-9055, ISSN 1339-8660, Volume 10 Issue 2, 2021 
v starobe plní úlohu multiplikátora aktívneho života, a zároveň c) je pre seniora určitým transmiterom medzi činnostami, ktoré sú zamerané na seba, a činnost’ami, ktoré majú využitie v širšom prostredí.

Pre starších dospelých v procese aktívneho starnutia a pre seniorov ${ }^{13}$ $\mathrm{v}$ procese aktívneho prežívania staroby nie je dôležitý intelektuálny výkon, ktorý dospelý človek $\mathrm{v}$ preddôchodkovom alebo seniorskom veku v edukácii podá, ale stopa, ktorú edukácia zanechá v ich živote (Hatar, 2019: 100), i ked', ako uvádzajú M. Stilec (2004: 14) alebo Z. Butorova et al. (2013a: 8), dnešná doba kladie dôraz viac na (pracovný) výkon, zdatnost', krásu a mladost'.

\section{Bibliographic references}

Active Ageing: A Policy Framework. Available online: http://apps.who.int/iris/bitstream/10665/67215/1/WHO_NMH_NPH_02.8.pd f

Active Ageing Index for 28 European Union Countries. Available online: https://www.unece.org/fileadmin/DAM/pau/age/WG7/Documents/Policy_Bri ef_AAI_for_EG_v2.pdf

ADAMEC, P. (ed.). 2015. Soucasna role celozivotniho uceni $\mathrm{v}$ zivote senioru z multidisciplinarni perspektivy. Brno: MU. 107 p. ISBN 978-80-210-79403.

Aktiv Altern: Rahmenbedingungen und Vorschlaege fuer politisches Handeln. Available online:

http://apps.who.int/iris/bitstream/10665/67215/2/WHO_NMH_NPH_02.8_ge r.pdf

ALAN, J. 1989. Etapy zivota ocima sociologie. Praha: Panorama. 440 p.

BALOGOVA, B. 2005. Seniori. Presov: Akcent Print. 158 p. ISBN 80969274-1-8.

BALTES, P. B. (ed.) et al. 1994. Alter und Altern. Ein interdisziplinaerer Studientext zur Gerontologie. Berlin: Walter de Gruyter. 814 p. ISBN 3-11014408-5.

BEELMANN, G. 2011. Gestaltung beruflicher Uebergaenge am Beispiel aelterer Arbeitnehmerinnen und Arbeitnehmer: Fallbeispiele aus der Praxis. In BEELMANN, W. - ROSOWSKI, E. (eds.). Uebergaenge im Lebenslauf bewaeltigen und foerderlich gestalten. Berlin: LIT Verlag, p. 135-150. ISBN 978-3-643-11468-6.

BERTERMANN, B. 2014. Geragogische Herausforderung der Hochaltrigkeit. In Zeitschrift fuer Gerontologie und Geriatrie, vol. 47, n. 7,

13 „Podl’a zistení Silverstein a Parker (2002) je maximalizácia participácie na aktivitách užívaná seniormi ako adaptačná stratégia kompenzujúca sociálne a fyzické deficity. Seniori, ktorí zvýšili svoju participáciu vaktivitách bez ohl'adu na ich typ, vykazovali zlepšenie svojich životných podmienok“" (Petrova Kafkova, 2019: 203). 
pp. 552-556. ISSN 1435-1269. Available online: https://link.springer.com/content/pdf/10.1007\%2Fs00391-014-0813-8.pdf BODNAROVA, B. 2009. Starnutie populacie a predlzovanie pracovneho zivota na Slovensku. In Rodina a praca, vol. 2009, n. 2, pp. 5 - 26. ISSN 1336-7153. Available online: https://www.ceit.sk/IVPR/images/pdf/bulletin_02_2009.pdf BUGELOVA, T. - CUPKOVA, L. 2020. Zivot a praca seniorov vo svetle teorii a vyskumov. Presov: PU. 104 p. ISBN 978-80-555-2415-3. Available online:

http://www.pulib.sk/web/pdf/web/viewer.html?file=/web/kniznica/elpub/dok ument/Bugelova1/subor/9788055524153.pdf

BUTOROVA, Z. et al. 2013a. Odporucania nastrojov na zmenu postojov a nazorov na aktivne starnutie na zaklade vysledkov empirickeho prieskumu. Bratislava: CV MPSVaR SR. 32 p. [cit. 2018-07-28]. Available online: https://www.ia.gov.sk/cv/images/projekty/strategiaaktivnehostarnutia/NPSA S_Aktivita3_Odporucania.pdf

BUTOROVA, Z. et al. 2013b. Stvrty rozmer tretieho veku. Desat kapitol o aktivnom starnuti. Bratislava: Institut pre verejne otazky. 368 p. ISBN 97880-89345-44-1.

CIMBALNIKOVA, L. et al. 2011. Age Management. Komparativni analyza podminek a pristupu vyuzivanych v Ceske republice a ve Finsku. Praha: AIVD CR. 82 p. ISBN 978-80-904531-2-8. Available online:

http://www.aivd.cz/soubor-doc738/

CIMBALNIKOVA, L. et al. 2012. Age Management pro praci s cilovou skupinou 50+. Metodicka prirucka. Praha: AIVD CR. 160 p. ISBN 978-80904531-5-9. Available online: http://www.aivd.cz/soubor-doc737/

CEPELKA, O. 2019. Satisfakcni a stimulacni efekty organizovaneho vzdelavani senioru. In Lifelong Learning - celozivotni vzdelavani, vol. 9, n. 3 , pp. 23-42. ISSN 1804-526X. Available online: https://lifelonglearning.mendelu.cz/media/pdf/LLL_20190903023.pdf

CEVELA, R. et al. 2014. Socialni gerontologie. Vychodiska ke zdravotni politice a podpore zdravi ve stari. Praha: Grada. 238 p. ISBN 978-80-2474544-2.

CEVELA, R. - KALVACH, Z. - CELEDOVA, L. 2012. Socialni gerontologie. Uvod do problematiky. Praha: Grada. 263 p. ISBN 978-80-2473901-4.

CORNANICOVA, R. 1998. Edukacia seniorov. Vznik, rozvoj, podnety pre geragogiku. Bratislava: UK. 156 p. ISBN 80-223-1206-1.

CORNANICOVA, R. 2011. Zaujmove vzdelavanie dospelych ako oblast kulturno-osvetovej andragogiky. In KRYSTON, M. et al. Zaujmove vzdelavanie dospelych. Teoreticke vychodiska. Banska Bystrica: UMB, p. 42 - 53. ISBN 978-80-557-0211-7. 
DEBNARIKOVA, M. - KADLUBEKOVA, D. 2017. Edukacia dospelych s mentalnym a viacnasobnym postihnutim - priklad dobrej praxe z Domova socialnych sluzieb Slatinka, prevadzka Nadej Vidina. In VETESKA, J. (ed.). Vzdelavani dospelych 2016 - vychodiska a inspirace pro teorii a praxi. Praha: CAS, p. 85-95. ISBN 978-80-905460-6-6.

DEBNARIKOVA, M. - KORICINA, M. 2020. Leisure activities and education of seniors in residential facilities. In AD ALTA, vol. 10, n. 2, pp. 195 - 200. ISSN 1804-7890, 2464-6733 (online). Available online: http://www.magnanimitas.cz/ADALTA/1002/papers/A_koricina.pdf

Definicia vekoveho manazmentu a vytvorenie zasad vekoveho manazmentu pre zamestnavatelov ( $\mathrm{v}$ sukromnej a verejnej sprave). Available online: https://www.employment.gov.sk/files/slovensky/ministerstvo/rada-vlady-srprava-seniorov/definicia-vekoveho-manazmentu-vytvorenie-zasad.pdf DU PREL, J. B. - SCHRETTENBRUNNER, Ch. - HASSELHORN, H. M. 2019. Vertikale und horizontale soziale Ungleichheit und Motivation zum vorzeitigen Erwerbsausstieg. In Zeitschrift fuer Gerontologie und Geriatrie, vol. 52, n. 1 supl., pp. 3-13. ISSN 1435-1269. Available online: https://link.springer.com/article/10.1007\%2Fs00391-018-1450-4

ENGSTLER, H. 2019. Wie erfolgreich sind aeltere Arbeitskraefte in der zeitlichen Umsetzung ihrer Ausstiegsplaene? Soziale Unterschiede der Uebereinstimmung zwischen geplantem und realisiertem Alter der Erwerbsbeendigung. In Zeitschrift fuer Gerontologie und Geriatrie, vol. 52, n. 1, supl., pp. 14-24. ISSN 1435-1269. Available online: https://link.springer.com/article/10.1007\%2Fs00391-018-1451-3

GEROK, W. - BRANDTSTAEDTER, J. 1994. Normales, krankhaftes und optimales Altern: Variations- und Modifikationsspielraeume. In BALTES, P. B. (ed.) et al. Alter und Altern. Ein interdisziplinaerer Studientext zur Gerontologie. Berlin: Walter de Gruyter, p. 356-385. ISBN 3-11-014408-5.

GRACOVA, D. - SELECKY, E. 2017. Vyvojove trendy edukacie seniorov na univerzitach tretieho veku v Europe. Banska Bystrica: Belianum. 150 p. ISBN 978-80-557-1378-6.

GRUEN, A. 2008. Umenie starnut. Bratislava: LUC. 160 p. ISBN 978-807114-688-9.

HARTL, P. - HARTLOVA, H. 2010. Velky psychologicky slovnik. 4. vydanie. Praha: Portal. 800 p. ISBN 978-80-7367-686-5.

HANOBIK, F. 2016. Sociálna politika EU a multikulturnost. Pribram: Ustav sv. Jana Nepomuka Neumanna. 192 p. ISBN 978-80-906146-7-3.

HASMANOVA MARHANKOVA, J. 2013. Aktivita jako projekt. Diskurz aktivniho starnuti a jeho odezvy v zivotech ceskych senioru a seniorek. Praha: SLON. 170 p. ISBN 978-80-7419-152-7.

HASMANOVA-MARHANKOVA, J. 2010. Konstruovani predstav aktivniho starnuti v centrech pro seniory. In Sociologicky casopis/Czech Sociological Review, vol. 46, n. 2, pp. 211-234. ISSN 2336-128X Available online: 
http://sreview.soc.cas.cz/uploads/3bc19175b82e08df28efe9eb21e4793d3ff00 fa9_Hasmanova.pdf

HASKOVCOVA, H. 2010. Fenomen stari. 2. vydanie. Praha: HBT. 368 p. ISBN 978-80-87109-19-9.

HATAR, C. 2019. Active Ageing and Active Old Age in the Educational Context. In AD ALTA, vol. 9, n. 1, pp. 97-102. ISSN 1804-7890, 2464-6733 Available online: http://www.magnanimitas.cz/ADALTA/0901/papers/A_hatar.pdf HATAR, C. 2014. Geragogika. Vybrane kapitoly z teorie a metodiky edukacie seniorov. Nitra: UKF. 110 p. ISBN 978-80-558-0666-2.

HATAR, C. - JEDLICKOVA, P. 2018. Cudzojazycne vzdelavanie dospelych ako priprava na starobu v Nemecku a Spanielsku. In VETESKA, J. (ed.). Vzdelavani dospelych 2017 - v dobe rezonujicich spolecenskych zmen / Adult education 2017 - in time of resonant social changes. Praha: CAS, p. 165-175. ISBN 978-80-906894-2-8.

HATAR, C. - JEDLICKOVA, P. 2020. The issue of active ageing and active old age in the education and social policy of Slovakia, Germany and Spain. In Lifelong Learning - celozivotni vzdelavani, vol. 10, n. 3, pp. 311-331. ISSN 1804-526X. Available online: https://lifelonglearning.mendelu.cz/media/pdf/LLL_20201003311.pdf

HEGYI, L. 2013. Seniori. In MORICOVA, S. - BARTOSOVIC, I. -

186 HEGYI, L. Znevyhodnene skupiny vo verejnom zdravotnictve. Bratislava: VEDA, p. 118 - 138. ISBN 978-80-224-1278-0.

HERMANOVA, E. 2012a. Koncepty, teorie a mereni kvality zivota. Praha: SLON. 239 p. ISBN 978-80-7419-106-0.

HERMANOVA, E. 2012b. Kvalita zivota a jeji modely v soucasnem sociálnim vyzkumu. In Sociologia, vol. 44, n. 4, pp. 407-425. ISSN 13368613. Available online: http://www.sav.sk/journals/uploads/09101219Hermanova\%20$\% 20 \mathrm{OK} \% 20$ upravena\%20studia.pdf HOFAECKER, D. - HESS, M. - KOENIG, S. 2019. Wandel von Ruhestandsuebergaengen im politischen Paradigmenwechsel Europas. Spaete Erwerbsphase und Rentenuebergang in Deutschland, Oesterreich, Schweden und Estland. In Zeitschrift fuer Gerontologie und Geriatrie, vol. 52, n. 1 supl., pp. 40-51. ISSN 1435-1269. Available online: https://link.springer.com/article/10.1007\%2Fs00391-018-01476-1

HOLCZEROVA, V. - DVORACKOVA, D. 2013. Volnocasove aktivity pro seniory. Praha: Grada. 96 p. ISBN 978-80-247-4697-5.

HORAK, J. 2002. Organizacia a riadenie socialnych zariadeni. Nepublikovane prednasky. Nitra: PF UKF.

HOTAR, V. - PASKA, P. - PERHACS, J. et al. 2000. Vychova a vzdelavanie dospelych. Andragogika. Terminologicky a vykladovy slovnik. Bratislava: SPN. 547 p. ISBN 80-08-02814-9. 
HVOZDIK, S. 2014. Psychologia starsich dospelych a poradenstvo starsim dospelym. Kosice: UPJS. 334 p. ISBN 978-80-8152-145-4.

ILMARINEN, J. 2008. Ako si predlzit aktivny zivot. Starnutie a kvalita pracovneho zivota v Europskej unii. Bratislava: Priroda. 467 p. ISBN 97880-07-01658-3.

IVANCIKOVA, M. 2020. Priprava na starnutie, starobu a vstup do dochodku ako jedna z klucovych zivotnych vyziev kazdeho cloveka. In Pedagogica actualis XI. Trnava: UCM, p. 157-163. ISBN 978-80-572-0045-1.

JANIS, K. - SKOPALOVA, J. 2016. Volny cas senioru. Praha: Grada. 156 p. ISBN 978-80-247-5535-9.

JEDLICKOVA, P. 2014a. Edukacia zdravotne znevyhodnenych dospelych a seniorov $v$ rezidencialnych zariadeniach. Nitra: UKF. 164 p. ISBN 978-80558-0611-2.

JEDLICKOVA, P. 2021. FIE as a form of pre-senior education. In INTED 2021. Valencia: IATED, p. 2681 - 2685. ISBN 978-84-09-27666-0.

JEDLICKOVA, P. 2017. Medzigeneracne ucenie v rodinnom prostredi ako prevencia agresivneho spravania u deti. Nitra: UKF. 108 p. ISBN 978-80558-1178-9.

JEDLICKOVA, P. 2014b. Proseniorska vychova v rodinach a institucionalizacia seniorov. Nitra: UKF. 76 p. ISBN 978-80-558-0667-9.

JERABEK, H. et al. 2013. Mezigeneracni solidarita v peci o seniory. Praha: SLON. 316 p. ISBN 978-80-7419-117-6.

JURCOVA, D. 2002. Kratky slovnik zakladnych demografickych pojmov. Bratislava: Institut informatiky a statistiky. 38 p. Available online: http://www.infostat.sk/vdc/pdf/slovnik2.pdf

KAMINSKA, D. 2017. Duchovni rozmer v peci o seniory. Nepublikovana prednaska. Praha: Centrum Senorina.

KALVACH, Z. et al. 1997. Uvod do gerontologie a geriatrie. 1. dil. Gerontologie obecna a aplikovana. Praha: Karolinum. 194 p. ISBN 80-7184366-0.

KOLLAND, F. 2010. Standortbestimmung der Geragogik. In MIKLAS, H. (ed.). Geragogik - eine Herausforderung der Zukunft. Wien: LIT Verlag, p. 9 - 24. ISBN 978-3-643-50214-8.

KOLLAND, F. - AHMADI, P. 2010. Bildung und aktives Altern. Bewegung im Ruhestand. Bielefeld: W. Bertelsmann Verlag. ISBN 978-3-7639-4288-6. Available online:

https://books.google.sk/books?hl=sk\&lr=lang_en\%7Clang_de\%7Clang_pl\% 7Clang_es\&id=131Hy9t4akMC\&oi=fnd\&pg=PA9\&dq=aktives+altern

KOLLAND, F. - MEYER SCHWEIZER, R. A. 2012. Altern und Wertewandel. In Zeitschrift fuer Gerontologie und Geriatrie, vol. 45, n. 7, pp. 587-592. ISSN 1435-1269. Available online: https://link.springer.com/article/10.1007\%2Fs00391-012-0392-5 
KOMENSKY, J. A. 1992. Vsevychova (Pampaedia). Bratislava: NOC. 272 p. ISBN 80-215-0216-9.

KORICINA, M. 2021. The curriculum of the pre-senior education programme. In INTED 2021. Valencia: IATED, p. 10601 - 10609. ISBN 978-84-09-27666-0.

KORICINA, M. 2020. Nove vyzvy pre volnocasovu edukaciu ludi v preseniorskom veku. In Pedagogica actualis XI. Trnava: UCM, p. 186-197. ISBN 978-80-572-0045-1.

KORNADT, A. E. - ROTHERMUND, K. 2011. Dimensionen und Deutungsmuster des Alterns. Vorstellungen vom Altern, Altsein und der Lebensgestaltung im Alter. In Zeitschrift fuer Gerontologie und Geriatrie, vol. 44, n. 5, pp. 291-298. ISSN 1435-1269. Available online: https://link.springer.com/article/10.1007\%2Fs00391-011-0192-3

KOSTOLNA, Z. 2009. Postavenie starsich osob na trhu prace vo svetle vyskumnych zisteni. In Rodina a praca, vol. 2009, n. 2, pp. 27-56. ISSN 1336-7153. Available online: https://www.ceit.sk/IVPR/images/pdf/bulletin_02_2009.pdf KOVAC, D. 2013. Umne starnut. Fragmenty. Bratislava: VEDA. 176 p. ISBN 978-80-224-1280-3.

KRICHELDORFF, C. 2014. Alter(n) lernen. In Zeitschrift fuer Gerontologie und Geriatrie, vol. 47, n. 7, pp. 549 - 551. ISSN 1435-1269. Available online: https://link.springer.com/article/10.1007\%2Fs00391-014-0814-7

KRICHELDORFF, C. - KLOTT, S. 2017. Altersbildung und Soziale Arbeit. In Zeitschrift fuer Gerontologie und Geriatrie, vol. 50, n. 5, pp. 434-438. ISSN 1435-1269. Available online: https://link.springer.com/article/10.1007\%2Fs00391-017-1255-x KRYSTON, M. et al. 2011. Zaujmove vzdelavanie dospelych. Teoreticke vychodiska. Banska Bystrica: UMB. 238 p. ISBN 978-80-557-0211-7.

KRYSTON, M. - KARIKOVA, S. 2015. Vzdelavanie seniorov. Andragogicke, geragogicke a psychologicke vychodiska. Banska Bystrica: UMB. 140 p. ISBN 978-80-557-0897-3.

KRUSE, A. 1994. Alter im Lebenslauf. In BALTES, P. B. (ed.) et al. Alter und Altern. Ein interdisziplinaerer Studientext zur Gerontologie. Berlin: Walter de Gruyter, p. 331-355. ISBN 3-11-014408-5.

KRIVOHLAVY, J. 2011. Starnuti z pohledu pozitivni psychologie. Moznosti, ktere cekaji. Praha: Grada. 141 p. ISBN 978-80-247-3604-4.

KUPCOVA, V. 2014. Zaujmove vzdelavanie dospelych $\mathrm{z}$ aspektu kvality. Banska Bystrica: Belianum. 146 p. ISBN 978-80-557-0744-0.

LALIK, M. 2012. Prace s pocitacem pro seniory. Praha: Grada. 152 p. ISBN 978-80-247-4136-9.

LALIK, M. 2013. Prace s pocitacem pro seniory 2. Praha: Grada. 149 p. ISBN 978-80-247-4594-7.

LENHARDTOVA, M. - FRK, V. - TLUCAKOVA, L. 2015. Tvorba 
kooperativnych edukacnych programov $\mathrm{v}$ rezidencialnych zariadeniach. Presov: PU. 79 p. ISBN 978-80-555-1535-9.

LIVECKA, E. 1979. Uvod do gerontopedagogiky. Praha: USI pri MS. 235 p. LIVECKA, E. - KUBALEK, J. 1978. Podnikova pedagogika. Praha: SPN. $335 \mathrm{p}$.

MACHALOVA, M. 2004. Psychologia vo vzdelavani dospelych. Od teorie k praxi. Bratislava: RadioPrint. 273 p. ISBN 80-969339-6-5.

MASARIK, P. et al. 1994. Vseobecna a porovnavacia pedagogika. Vybrane kapitoly. Nitra: VSPg. 152 p. ISBN 80-88-738-16-4.

MASARIKOVA, A. - MASARIK, P. 2002. Vybrane kapitoly z pedagogiky volneho casu. Nitra: UKF. 208 p. ISBN 80-968735-0-4.

MESZAROSOVA, J. - WSOLOVA, L. - GAZDIKOVA, K. 2017. Sociálne aspekty starnutia - priprava na dochodkovy vek. In Verejne zdravotnictvo, vol. 13, n. 1, pp. 18-34. ISSN 1337-1789. Available online: http://casopis.fvszu.sk/wp-content/uploads/201701meszarosovawsolovagazdikova.pdf

MITTERLECHNER, Ch. 2012. Staroba neznamena koniec. In Socioterapia, vol. 2, n. 2, pp. 8-10. ISSN 1331-7138. Available online: https://www.socioterapia.sk/wpcontent/uploads/2018/08/Socioterapia_2_2012.pdf

MUHLPACHR, P. 2004. Gerontopedagogika. Brno: MU. 204 p. ISBN 80210-3345-2.

MUELLER DE MORAIS, M. 2019. Preparation for Old Age as Part of the Adaptation to Old Age. In AD ALTA, vol. 9, n. 2, pp. 215-219. ISSN 18047890, 2464-6733 (online). Available online: http://www.magnanimitas.cz/ADALTA/0902/papers/A_mullerdemorais.pdf Narodna klasifikacia vzdelania. Available online: https://www.minedu.sk/data/files/3772.pdf

NOVOTNY, P. et al. 2014. Age management: Jak rozumet starnuti a jak na nej reagovat. Moznosti uplatneni age managementu v Ceske republice. Pruvodce pro jednotlivce, organizace a spolecnost. Praha: AIVD. 144 p. ISBN 978-80-904531-7-3. Available online: http://www.aivd.cz/soubordoc736/

ONDRUSOVA, J. 2011. Stari a smysl zivota. Praha: Karolinum. 168 p. ISBN 978-80-246-1997-2.

OSWALD, W. D. 2000. Sind Alter und Altern meßbar? In Zeitschrift fuer Gerontologie und Geriatrie, vol. 33, n. 1 supl., pp. 8-14. ISSN 1435-1269. Available online: https://link.springer.com/article/10.1007/s003910070002 PACOVSKY, V. 1990. O starnuti a stari. Praha: AVICENUM. 136 p. ISBN 80-201-0076-8.

PERHACS, J. 2004. Geragogika. Nepublikovane prednasky. Nitra: PF UKF. 
PERHACS, J. 2011. Personalizacne a socializacne aspekty rozvoja osobnosti dospelych. 2. upravene vydanie. Praha: Rozlet a CAS. 157 p. ISBN 978-80904824-4-9.

PERHACS, J. - PASKA, P. 1995. Dospely clovek v procese vychovy. Bratislava: Stimul. 158 p. ISBN 80-85697-21-1.

PETLAK, E. 1997. Vseobecna didaktika. Bratislava: Iris. 275 p. ISBN 8088778-49-2.

PETROVA, G. 2013. Priprava dospelych na starobu prostrednictvom vzdelavania. In HATAR, C. (ed.). Vplyv edukacie na kvalitu zivota seniorov. Nitra: UKF, p. 117-123. ISBN 978-80-558-0249-7.

PETROVA KAFKOVA, M. 2012. Dobrovolnictvi senioru jako soucast aktivniho starnuti. In Sociologia, vol. 44, n. 2, pp. 212-232. ISSN 1336-8613. Available online: http://www.sav.sk/journals/uploads/05241016PetrovaKafkova2\%20-\%20upravena\%20studia.pdf

PETROVA KAFKOVA, M. 2019. Preference aktivniho zivotniho stylu v kontextu veku a miry ekonomickeho, socialniho a kulturniho kapitalu. In Sociologia, vol. 51, n. 2, pp. 198-218. ISSN 1336-8613. Available online: https://www.sav.sk/journals/uploads/04231107Petrova\%20Kafkova\%202-

2019.pdf

PETROVA KAFKOVA, M. - SEDLAKOVA, T. 2017. Ctvrty vek jako specificke pole pro vyjadreni akterstvi. In Sociologicky casopis/Czech

190 Sociological Review, vol. 53, n. 5, pp. 719-735. ISSN 2336-128X (online). Available online: http://sreview.soc.cas.cz/uploads/abd86eb08ceb1042bdaae8f249c88caca0ba1 cc0_17-5-04Petrova16.pdf

PETRKOVA, A. - CORNANICOVA, R. 2004. Gerontagogika. Uvod do teorie a praxe edukace senioru. Olomouc: UP. 92 p. ISBN 80-244-0879-1.

PISONOVA, M. et al. 2017. Skolsky manazment - terminologicky a vykladovy slovnik. Bratislava: Wolters Kluwer. 168 p. ISBN 978-80-8168660-3.

PORUBSKA, G. - DURDIAK, L. 2005. Manazment vzdelavania dospelych. Nitra: SlovDidac. 212 p. ISBN 80-969303-0-3.

Pro Senectute. Available online: https://www.prosenectute.ch/

RABUSICOVA, M. et al. 2016. Mezigeneracni uceni. Teorie, vyzkum, praxe. Brno: MU. 296 p. ISBN 978-80-210-8460-5.

RABUSICOVA, M. - KAMANOVA, L. - PEVNA, K. 2011. O mezigeneracnim uceni. Brno: MU. 210 p. ISBN 978-80-210-5750-0.

RACKOVA, A. - OCHABA, R. (eds.). 2012. Aktivne starnutie. Bratislava: Urad verejneho zdravotnictva SR. 16 p. Available online:

http://www.uvzsr.sk/docs/info/podpora/letaky/Aktivne_starnutie_brozura.pdf RACZOVA, B. - MARHEVSKA, G. 2013. Priprava na starnutie v kontexte sebakontroly a starostlivosti o seba: vysledky vyskumu. In Psychologie a jeji 
kontexty, vol. 4, n. 1, pp. 37-50. ISSN 1805-9023 (online). Available online: https://psychkont.osu.cz/fulltext/2013/Raczova,Marhevska_2013_1.pdf

REPKOVA, K. 2012. Dobrovolnictvo v kontexte aktivneho starnutia: konceptualna evolucia a pretrvavajuce stereotypy. In Rodina a praca, vol. 2012, n. 4, 46 p. ISSN 1336-7153.

SAK, P. - KOLESAROVA, K. 2012. Sociologie stari a senioru. Praha: Grada. 225 p. ISBN 978-80-247-3850-5.

SAUP, W. - TIETGENS, H. et al. 1992. Bildung fuer ein konstruktives Altern. Frankfurt a. M.: Paedagogische Arbeitsstelle des DVV. 77 p. ISBN 388513-427-6. Available online: http://www.diefrankfurt.de/esprid/dokumente/doc-1992/saup92_01.pdf

SCHUNOVA, R. 2019. Analyza dokumentov o aktivnom starnuti na Slovensku a v zahranici. In MAYER, K. (ed.). Teoria a prax edukacie dospelych. Presov: PU, p. 161-170. ISBN 978-80-555-2218-0. Available online:

http://www.pulib.sk/web/pdf/web/viewer.html?file=/web/kniznica/elpub/dok ument/Mayer2/subor/zbornik.pdf

SINAY, J. - SVIDEROVA, K. 2013. Bezpecnost pri praci vo vyssom veku. Kosice: TU. 112 p. ISBN 978-80-553-1444-0.

SLADKAYOVA, M. 2019. Obcianske vzdelavanie dospelych. Banska Bystrica: Belianum. 98 p. ISBN 978-80-557-1535-3.

Slovenske slovniky. Available online: http://slovniky.juls.savba.sk/

STRIEZENEC, S. 1999. Uvod do socialnej prace. Trnava: Vydavatelstvo AD. 216 p. ISBN 80-967589-6-9.

STRIZENEC, M. 2007. Novsie psychologicke pohlady na religiozitu a spiritualitu. Bratislava: Ustav experimentalnej psychologie SAV. 166 p. ISBN 978-80-88910-24-4. Available online:

http://www.psychologia.sav.sk/upload/MS_Novsie-psychologicke-pohladyna-religiozitu-a-spiritualitu.pdf

SERAK, M. 2019. Priprava na starnuti - konceptualizace problematiky. In SERAK, M. - TOMCZYK, L. (eds.). Preparation to Ageing and Old Age. Krakow: UP, p. 13 - 39. ISBN 978-83-953737-2-5. Available online: https://www.researchgate.net/publication/337389448_PREPARATION_TO_ AGEING_AND_OLD_AGE/link/5dd51914299bf11ec8630893/download SERAK, M. 2009. Zajmove vzdelavani dospelych. Praha: Portal. 208 p. ISBN 978-80-7367-551-6.

SPATENKOVA, N. - SMEKALOVA, L. 2015. Edukace senioru. Geragogika a gerontodidaktika. Praha: Grada. 232 p. ISBN 978-80-2475446-8.

Statne vzdelavacie programy. Available online: https://www.minedu.sk/8387-sk/statne-vzdelavacie-programy/

STILEC, M. 2004. Program aktivniho stylu zivota pro seniory. Praha: Portal. 136 p. ISBN 80-7178-920-8. 
STOROVA, I. 2015. Age management pro zamestnavatele se zamerenim na starsi pracovniky. Praha: SPaD CR. 42 p. Available online: http://www.aivd.cz/soubor-doc740/

SVEC, S. 2008. Anglicko-slovensky lexikon pedagogiky a andragogiky. Bratislava: Iris. 323 p. ISBN 978-80-89256-21-1.

SVEC, S. 2015. Edukacia. In SVEC, S. (ed.). Slovenska encyklopedia edukologie. Bratislava: UK, p. 223 - 232. ISBN 978-80-223-3747-2.

SVEC, S. (ed.). 2015. Slovenska encyklopedia edukologie. Bratislava: UK. 1391 p. ISBN 978-80-223-3747-2.

THEUNISSEN, G. 2002. Altenbildung und Behinderung. Impulse fuer die Arbeit mit Menschen, die als lern- und geistig behindert gelten. Bad Heilbrunn: Verlag Julius Klinkhardt. 207 p. ISBN 3-7815-1184-7.

TESCH-ROEMER, C. 2012. Aktives Altern und Lebensqualitaet im Alter. In Informationsdienst Altersfragen, vol. 39, n. 1, pp. 3- 9. ISSN 0724-8849. [cit. 2020-02-23]. Available online: https://www.dza.de/fileadmin/dza/pdf/Heft_01_2012_Januar_Februar_2012_ gesamt_PW.pdf

TOKAROVA, A. 2002. K metodologickym otazkam vyskumu a hodnotenia kvality zivota. In TOKAROVA, A. (ed.). Kvalita zivota $\mathrm{v}$ kontextoch globalizacie a vykonovej spolocnosti. Presov: PU, pp. 11-29. ISBN 80-8068087-6.

192 TOMCZYK, L. 2015. Vzdelavani senioru v oblasti novych medii. Praha: AIVD CR. 240 p. ISBN 978-80-904531-9-7.

TOMES, I. - BOCKOVA, L. 2017. Povinna a dobrovolna solidarita se starnoucimi a starymi lidmi. In TOMES, I. - SAMALOVA, K. (eds.) et al. Sociálni souvislosti aktivniho stari. Praha: UK Karolinum, pp. 9-48. ISBN 978-80-246-3612-2.

TOMES, I. - SAMALOVA, K. (eds.) et al. 2017. Sociálni souvislosti aktivniho stari. Praha: UK Karolinum. 256 p. ISBN 978-80-246-3612-2.

URBAN, L. 2017. Sociologie. Klicova temata a pojmy. Praha: Grada. 228 p. ISBN 978-80-247-5774-2.

UNKELBACH-ROMUSSI, G. 1997. Grundlinien einer Didaktik und Methodik der Altersvorbereitung. Frankfurt am Main-Berlin-Bern-New York-Paris-Wien: Peter Lang. Europaeischer Verlag der Wissenschaften. 209 p. ISBN 3-631-32083-3.

VASKA, L. 2014. Sluzby zamestnanosti a vybrane aspekty socialnej prace s nezamestnanymi. Bratislava: IRIS. 224 p. ISBN 978-80-89726-25-7.

VAVRIKOVA, H. 2017. Edukace dospelych jako prostredek prevence ageismu. Dizertacna praca. Banska Bystrica: PF UMB.

VAVRIKOVA, H. - HUDECOVA, A. 2018. Ageismus jako projev stereotypizace a diskriminace senioru a možnosti jeho prevence prostrednictvim edukace dospelych. Banska Bystrica: Belianum. 404 p. ISBN 978-80-557-1386-1. 
VAGNEROVA, M. 2000. Vyvojova psychologie. Detstvi - dospelost - stari. Praha: Portal. 522 p. ISBN 80-7178-308-0.

WALSH, D. 2005. Skupinove hry a cinnosti pro seniory. Praha: Portal. 204 p. ISBN 80-7178-970-4.

WERNER, R. L. 2012. Bildung im Alter. Ueberlegungen zur Allgemeinbildung im demografischen Wandel. Hamburg: Verlag Dr. Kovac. 237 p. ISBN 978-3-8300-6163-2.

WINGCHEN, J. 1995. Geragogik. Lehr- und Arbeitsbuch fuer Altenpflegeberufe. Hagen: Brigitte Kunz Verlag. 202 p. ISBN 3-89495-0331.

Zakon c. 568/2009 Z. z. o celozivotnom vzdelavani v zneni neskorsich predpisov. Available online: https://www.slov-lex.sk/pravnepredpisy/SK/ZZ/2009/568/20150901

Zakon c. 448/2008 Z. z. o socialnych sluzbach v zneni neskorsich predpisov. Available online: https://www.slov-lex.sk/pravne-predpisy/SK/ZZ/2008/448/ Zakon c. 245/2008 Z. z. o vychove a vzdelavani v zneni neskorsich predpisov. Available online: https://www.slov-lex.sk/pravnepredpisy/SK/ZZ/2008/245/

Zakon c. 131/2002 Z. z. o vysokych skolach v zneni neskorsich predpisov. Available online: https://www.slov-lex.sk/pravne-predpisy/SK/ZZ/2002/131/ ZIMERMANOVA, M. 2013. Cooperation between Children and Seniors and Its Impact on the Quality of Life in Residential Care Conditions. In The New Educational Review, vol. 33, n. 3, pp. 19-32. ISSN 1732-6729.

ZIMERMANOVA, M. 2012a. Edukacia a ergoterapia ako determinanty kvality zivota seniorov $v$ rezidencialnych zariadeniach. Nitra: UKF. 73 p. ISBN 978-80-558-0089-9.

ZIMERMANOVA, M. 2012b. Kooperacia deti a seniorov v rezidencialnych podmienkach. Nitra: UKF. 102 p. ISBN 978-80-558-0177-3.

ZEMBEROVA, V. 2014. Prinos umeleckej literatury do casu zrelosti. In BALOGOVA, B. - SKYBA, M. (eds.). Socialny kapital starnutia pritomnost nikdy nestarne. Presov: PU, pp. 438-447. ISBN 978-80-555-10835 .

prof. PaedDr. Ctibor Határ, PhD.

Faculty of Education

Drážovská 4, 94974 Nitra

Slovakia

chatar@ukf.sk 